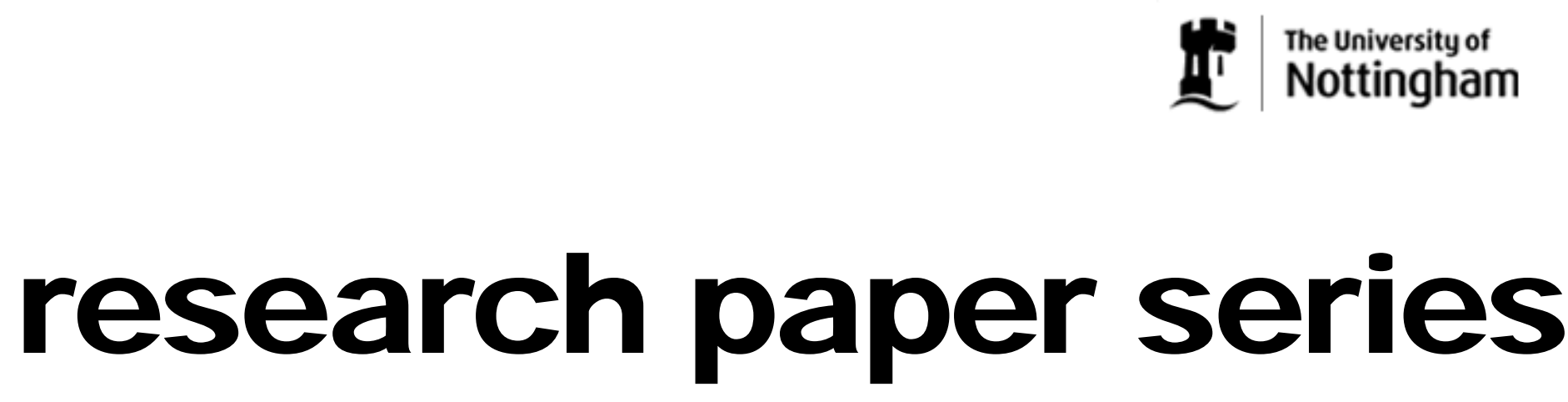

Globalisation and Labour Markets

Research Paper 2007/20

Unions and Globalisation

by

Marta Aloi, Manuel Leite-Monteiro and Teresa Lloyd-Braga

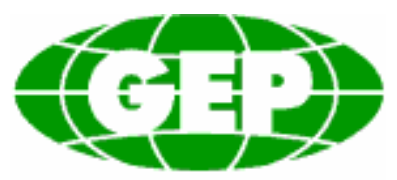

Leverhulme Centre 


\section{The Authors}

Marta Aloi is a Lecturer in the School of Economics at University of Nottingham and an Internal Research Fellow in GEP. Manuel Leite-Monteiro is an Assistant Professor at the Catholic University of Portugal, Lisbon. Teresa Lloyd-Braga is an Associate Professor at the Catholic University of Portugal, Lisbon. She is also affiliated to the CEPR, London.

\section{Acknowledgements}

We acknowledge Richard Disney, Daniel Seidmann and the participants to GEP research seminars for their useful comments. Marta Aloi gratefully acknowledges financial support form The Leverhulme Trust under Programme Grant F114/BF. 


\title{
Unions and Globalisation
}

by

Marta Aloi, Manuel Leite-Monteiro and Teresa Lloyd-Braga

\begin{abstract}
We analyze the effects of international integration of product and capital markets (i.e., globalisation) in a world where countries differ in their labour market institutions: one country has a perfectly competitive labour market while the other is unionized. We show that workers should favour autarky in the unionized country, but oppose it in the non unionized country. Vice versa for owners of capital. Aggregate gains from integration, however, are negative. We also show that, under capital mobility an increase in relative bargaining power of unions does not always improve workers' welfare: there is a critical level of bargaining strength above which an increase in union power reduces workers' income in the unionized country.
\end{abstract}

JEL classification: F20, J50

Keywords: Capital mobility, Unions, Globalisation

\section{Outline}

1. Introduction

2. The model

3. Autarky

4. Capital mobility

5. Conclusions 


\section{Non-Technical Summary}

Free trade and liberalization of capital movements are often associated with the notion of globalisation, that is the process of international economic integration of the world economy. Although in the past the world has experienced other episodes of globalisation, the most recent one has the peculiarity of being characterized by a very rapid integration of world capital markets. Trade unions tend to fear free trade and capital markets liberalisation, their main concern being that before liberalisation takes place workers of the trading partner countries should be granted essential rights, preferably similar to those enjoyed by home workers. Unions claim that this requisite is aimed at benefiting all workers, the struggle being between workers and capital owners around the world and not between workers from different countries. As a matter of fact workers' resistance to the current process of globalisation and increased international competition is widespread in developed countries, and workers are increasingly feeling left out from sharing the gains of international economic integration. On the other hand, many of those who are in favour of liberalisation of world economic transactions claim that unions aim merely at protecting their members against competition from workers of less regulated countries.

This paper provides a simple formal model in which such issue can be analysed. The conventional approach in the literature is to assume perfect competition in all markets and account for differences in returns by appealing to differences in fundamentals such as factor endowments, technologies or preferences. However, differences in market structure across countries may also cause the existence of differences in factor returns. For instance, unions with a sufficiently strong bargaining power in the labour market are usually able to ensure an income for their members (workers) higher than the level of wages that would be observed under perfect competition. Indeed, in a closed economy, unions are able to influence the distribution of income to the benefit of workers and at the expense of capital owners and of lower returns to capital. Accordingly, if union bargaining power differs across countries factor returns would be different and we would expect international factor movements to occur if these were liberalized.

We set out a static model with two countries, each producing the same single good (hence there is no trade based on comparative advantage) using the same technology and having the same fixed level of capital and labour endowments under autarky. Symmetry allows us to focus on how, in an integrated world economy, divergences in the labour market structure across countries, per se, affect income levels and their distribution between capital owners and workers. We assume that there is perfect competition in the output and capital service markets. Hence, had both countries enjoyed perfect competition in the labour market, or the same degree of union bargaining power, no capital movements would occur because factor returns in the autarkic equilibrium would be the same in both countries.

We show that, with capital mobility, capital flows out of the highly unionised into the less unionised country and that such capital flows are inefficient at the world level, since capital movements are ultimately due to labour market distortions. Therefore, contrary to standard models (that is models in which factor movements are driven by differences in factor productivities) international capital mobility induces a decrease in output at the world level. Furthermore, the capital share of world output increases at the expense of workers' share of world output. In the paper, we also study the effects on workers' income of changes in the relative bargaining power between firms and unions. We show that, under free international capital mobility, an increase in union power in the highly unionised country may not work to the benefit of workers since it induces additional capital outflows with negative effects on labour productivity and on the marginal contribution of capital to output 


\section{Introduction}

In the present paper we discuss the effects of international capital movements on factor income and welfare when union bargaining power differs across countries. We show that capital flows out of the highly unionised into the less unionised country and that such capital flows are inefficient at the world level, since capital movements are ultimately due to labour market distortions. Therefore, contrary to standard models, ${ }^{1}$ international capital mobility induces a decrease in output at the world level. Furthermore, the capital share of world output increases at the expense of workers' share of world output. In the paper, we also study the effects on workers' income of changes in the relative bargaining power between firms and unions. We show that, under free international capital mobility, an increase in union power may not work to the benefit of union members. In fact, in contrast to what happens under autarky, under capital mobility an increase in union power does not always increase workers' income, since it induces additional capital outflows.

Differences in factor returns across countries are considered to be an important source of international factor movements. The conventional approach in the literature is to assume perfect competition in all markets and account for differences in returns by appealing to differences in fundamentals such as factor endowments, technologies or preferences. However, differences in market structure across countries may also cause the existence of differences in factor returns. For instance, unions with a sufficiently strong bargaining power in the labour market are usually able to ensure an income for their members (workers) higher than the level of wages that would be observed under perfect competition. Indeed, in a closed economy, unions are able to influence the distribution of income to the benefit of workers and at the expense of capital owners and of lower returns to capital. Accordingly, if union bargaining power differs across countries factor returns would be different and

\footnotetext{
${ }^{1}$ That is models in which factor movements are driven by differences in factor productivities.
} 
we would expect international factor movements to occur if these were liberalised.

Free trade and liberalisation of capital movements are often associated with the notion of globalisation, that is the process of international economic integration of the world economy. Although in the past the world has experienced other episodes of globalisation, the most recent one has the peculiarity of being characterised by a very rapid integration of world capital markets. ${ }^{2}$ Trade unions tend to fear free trade and capital markets liberalisation, their main concern being that before liberalisation takes place workers of the trading partner countries should be granted essential rights, preferably similar to those enjoyed by home workers. Unions claim that this requisite is aimed at benefitting all workers, the struggle being between workers and capital owners around the world and not between workers from different countries. ${ }^{3}$ As a matter of fact workers' resistance to the current process of globalisation and increased international competition is widespread in developed countries, and workers are increasingly feeling left out from sharing the gains of international economic integration. ${ }^{4}$ On the other hand, many of those who are in favour of liberalisation of world economic transactions claim that unions aim merely at protecting their members against competition from workers of less regulated countries. The contribution of our paper is to provide a simple formal model in which such issues can be analysed.

\footnotetext{
${ }^{2}$ See the volume edited by M. Bordo, Alan Taylor and Jeffrey Williamson (2003) for a survey.

${ }^{3}$ This is the position of the general secretary of the International Confederation of Free Trade Unions (Guy Ryder) and of the general secretary of the World Confederation of labour (Willy Thys): "It is argued that the doubling of the global labour force with the entry of Chinese, Russian and Indian workers has changed the labour-capital ratio to the disadvantage of wage levels. Trade unions do not want anyone excluded from the global economy nor believe they can be. But they do want it subjected to reasonable regulations applicable to all countries, along with respect for workers' rights. Similarly, capital will continue to be internationally mobile and the world division of labour will evolve accordingly." (Financial Times, October 27th, 2006).

${ }^{4}$ The existing evidence on workers' perceived impact of globalisation as a race to the bottom, applies to both strongly unionised countries (e.g. Germany, France) and countries where trade unions are weak and unemployment is low (e.g. U.S., U.K.). See for instance the work by Schieve and Slaughter (2001), providing evidence that workers in the US increasingly fear the distributional consequences of globalisation, and similar findings are reported by ILO (1999) for a wide sample of countries.
} 
We set out a static model with two countries, each producing the same single good, ${ }^{5}$ using the same technology and having the same fixed level of capital and labour endowments under autarky. Symmetry allows us to focus on how, in an integrated world economy, divergences in the labour market structure across countries, per se, affect income levels and their distribution between capital owners and workers. We assume that there is perfect competition in the output and capital service markets. Hence, had both countries enjoyed perfect competition in the labour market, or the same degree of union bargaining power, no capital movements would occur because factor returns in the autarkic equilibrium would be the same in both countries. It is, therefore, the difference in union power between countries that causes differences in capital returns, which in turn induces capital movements once liberalisation takes place.

To simplify the analysis, we assume that in one of the two countries there is perfect competition in the labour market (that is union power approaches zero), while in the other country the labour market is unionised. We show that, when capital movements are liberalised, capital flows from the unionised into the non unionised country. As a result, workers' income decreases, as well as output, while capitalists' income increases in the unionised country. Vice versa in the non unionised country. At the world level, income per capita and workers' share of world output decrease. Therefore, international capital mobility would not benefit workers, even if the gains obtained by capital owners were efficiently redistributed among all individuals, both at the world level and in the unionised country. This may explain unions' resistance towards globalisation in a world with disparate workers' bargaining strength. In the paper we also address the issue of what is the desirable level of union bargaining power in the presence of internationally mobile capital. It is shown that there is a critical level of union power above which an increase in union strength reduces

\footnotetext{
${ }^{5}$ Hence there is no trade based on comparative advantage.
} 
union members' income.

The remainder of the paper is as follows. In Section 2 we present the model. In Section 3 we describe the autarkic equilibrium. In Section 4 we explore the effects of capital mobility, and Section 5 concludes.

\section{The model}

We consider a simple static model of two countries identical in everything except for the union bargaining power. In each country there are $\bar{K}$ capitalists and $\bar{N}$ workers, each exogenously supplying one unit of their respective factor service. Both countries produce the same single good, taken as numeraire, with identical constant returns to scale technologies. In each country there is a large number $M$ of identical firms, each firm producing $y^{j}$ units of output according to the following production function: $y^{j}=F\left(k^{j}, l^{j}\right), j=A, B$; where $k^{j}$ and $l^{j}$ represent, respectively, the units of capital and labour used in production by a firm in country $j$.

Assumption 1. $F\left(k^{j}, l^{j}\right)$ is a real, concave increasing continuous function for $\left(k^{j}, l^{j}\right) \in \Re_{+}^{2}$, positively valued and differentiable as many times as needed for $\left(k^{j}, l^{j}\right) \in \Re_{++}^{2}$, with $F_{k}>0$ and $F_{l}>0$. Moreover, $F$ is homogeneous of degree one in $k^{j}$ and $l^{j}$, with a constant elasticity of substitution $\sigma \in[1, \infty)$, where $\frac{1}{\sigma}=\frac{F_{k k} k}{F_{k}} /\left(1-\frac{F_{k} k}{F}\right)$.

Capital is rented in a perfectly competitive market at the rental rate $r^{j}$, while wages and employment are determined through efficient bargaining between unions and firms. Unions are firm specific and workers are uniformly distributed among them. Hence, each union represents $n^{j} \equiv \bar{N} / M$ workers and takes its number of members as given. ${ }^{6}$ We assume that workers own private pension assets, ${ }^{7}$ that

\footnotetext{
${ }^{6}$ In many developed countries' labour markets wage bargaining occurs at increasing decentralised levels. Katz (1993), among others, reports evidence of the decetralisation in the structure of collective bargaining in most developed economies since the early 1980s.

${ }^{7}$ This set up can be justified in a more general model by assuming that, in this economy, capital
} 
is they are also members of pension funds, and the latter invest only in domestic corporate stocks. ${ }^{8}$ To diversify their portfolio pension funds own an equal amount of every domestic firm. Accordingly, at a symmetric equilibrium, each worker receives $1 / \bar{N}$ of each firm dividends out of his/her pension assets. For each union the objective is to maximize the income of their members (wage and dividend earnings), while firms' objective is to maximize profits.

We consider a two-stage game and assume that in the first stage firms precommit to a given level of capital $\left(k^{j}\right)$ knowing that the wage, $w^{j}$, and employment, $l^{j}$, will be negotiated afterwards in the second stage of the game. To obtain the efficient bargaining solution we solve the generalized Nash bargaining problem, where the firm and union returns are net of their respective fallback (that is, net of the level of their returns in case no agreement takes place and $\left.l^{j}=0\right)$. Accordingly, $w^{j}$ and $l^{j}$ are the solutions of the following problem,

$$
\operatorname{Max}_{w^{j}, l^{j}}\left[F\left(k^{j}, l^{j}\right)-w^{j} l^{j}\right]^{1-\gamma^{j}}\left[w^{j} l^{j}\right]^{\gamma^{j}}, \quad \text { s.t. } l^{j} \leq n^{j}
$$

where $1>\gamma^{j} \geq 0$ represents country $j$ 's union bargaining power, $F\left(k^{j}, l^{j}\right)-w^{j} l^{j}$ represents the firm's profits net of its fallback (that is, net of capital rental cost $r^{j} k^{j}$ ), and $w^{j} l^{j}$ represents the income of union members net of their fallback (that is, net of the income coming from their private pension assets). The solution to this problem is: $l^{j}=n^{j}$ and $w^{j}=\gamma^{j} F\left(k^{j}, n^{j}\right) \frac{1}{n^{j}} \cdot{ }^{9}$ By anticipating this bargaining outcome, the

owners are risk neutral while workers are risk averse and want to ensure themselves against future income uncertainties.

${ }^{8}$ Private pension funds (and other means of private old-age maintenance) are particularly widespread among workers in anglosaxon countries; while in many other countries, inside and outside the Oecd - that have traditionally relied on unfunded wage related pensions - private funded pensions are increasingly taking over. The strong home bias displayed by pension and other institutional assets in Oecd countries is widely documented. For instance, in the Netherlands and Switzerland (which are the countries with the highest pension assets share in GDP among Oecd members), foreign asset shares as percentage of total of pension funds only amounted to an average of $10 \%$ in 1993 . In the same period, foreign asset shares as percentage of total pension funds was less than $5 \%$ in the US.

${ }^{9}$ Note that workers' bargained wage is higher than the perfectly competitive wage $\left(F_{l}\right)$, provided 
representative firm will choose to commit to the level of capital that maximizes profits, $\left(1-\gamma^{j}\right) F\left(k^{j}, n^{j}\right)-r^{j} k^{j}$, which leads to the first order condition: $r^{j}=$ $\left(1-\gamma^{j}\right) F_{k}\left(k^{j}, n^{j}\right)$. Using the Euler relations for the production function, it is easy to obtain the equilibrium levels of profits: $\left(1-\gamma^{j}\right) F_{l}\left(k^{j}, n^{j}\right) n^{j}$. At the symmetric equilibrium, each worker receives from its pension fund assets the equivalent to profits of one firm and, therefore, income per worker becomes: $w^{* j}=\gamma^{j} \frac{F\left(k^{j}, n^{j}\right)}{n^{j}}+$ $\left(1-\gamma^{j}\right) F_{l}\left(k^{j}, n^{j}\right)$, which can also be written as $F_{l}\left(k^{j}, n^{j}\right)+\gamma^{j} F_{k}\left(k^{j}, n^{j}\right) \frac{k^{j}}{n^{j}}$.

Exploiting symmetry of equilibrium, and the property of homogeneity of the production function, aggregate output is given by $Y^{j}=F\left(K^{j}, L^{j}\right)$, where $K^{j} \equiv$ $M k^{j}$ and $L^{j} \equiv M l^{j}$ represent countries' total capital and labour services utilization. Since equilibrium in the labour market requires that $L^{j}=\bar{N}$, the equilibrium values for factors' income can be written as,

$$
\begin{aligned}
r^{j} & =\left(1-\gamma^{j}\right) F_{K}\left(K^{j}, \bar{N}\right) \\
w^{* j} & =F_{L}\left(K^{j}, \bar{N}\right)+\gamma^{j} F_{K}\left(K^{j}, \bar{N}\right) \frac{K^{j}}{\bar{N}} .
\end{aligned}
$$

While equilibrium factors' (domestic) income shares correspond to,

$$
\begin{aligned}
& s_{K}^{j} \equiv \frac{r^{j} K^{j}}{F^{j}}=\left(1-\gamma^{j}\right) \frac{F_{K}\left(K^{j}, \bar{N}\right) K^{j}}{F\left(K^{j}, \bar{N}\right)} \\
& s_{L}^{j} \equiv \frac{w^{* j} \bar{N}}{F^{j}}=1-\left(1-\gamma^{j}\right) \frac{F_{K}\left(K^{j}, \bar{N}\right) K^{j}}{F\left(K^{j}, \bar{N}\right)} .
\end{aligned}
$$

Note that when $\gamma^{j}=0$ we recover the case of a perfectly competitive market; the rental costs of capital and labour income corresponding to their marginal products and, given the joint assumptions of constant returns and perfect competition, zero equilibrium profits. Compared to the perfectly competitive case, in the unionised country labour earns above its marginal product and the return to capital is below that union power is sufficiently strong, i.e., $\gamma>\frac{F_{l} l}{F}$. 
its marginal product. ${ }^{10}$

\section{Autarky}

At the autarkic equilibrium $K^{j}=\bar{K}$, with $j=A, B$, and $Y^{A}=F(\bar{K}, \bar{N})=Y^{B}$.

Two results are now worth emphasizing, for further comparison with the case of international capital mobility. First, since technologies and factor endowments are completely symmetric across countries, $K^{A}=K^{B}=\bar{K}$ represents the world efficient allocation and, therefore, world output is maximized at the autarkic equilibrium. Second, although the two countries have the same aggregate output, the income distribution between workers and capital owners differs, since it depends on the union bargaining power. Accordingly, workers' income and workers' income share are higher, while capital rentals and capital share in output are lower, the higher is the union bargaining power. In fact, differentiating (2) with respect to $\gamma$ we obtain,

$$
\left.\frac{d w^{* j}}{d \gamma^{j}}\right|_{A u t}=F_{K}(\bar{K}, \bar{N}) \frac{\bar{K}}{\bar{N}}>0 .
$$

We can then establish the following property.

Proposition 1 . Under autarky, an increase (decrease) in union bargaining power increases (decreases) workers' per capita income.

By use of (4), the effect of an increase in $\gamma$ on workers' income shares is given by $\left.\frac{d s_{L}^{j}}{d \gamma}\right|_{A u t}=F_{K}(\bar{K}, \bar{N}) \frac{\bar{K}}{F^{j}}$, which is also positive. Hence, in a closed economy where inputs are fully utilized, the higher the union power the better off are the workers as they can appropriate a larger share of income. If capital movements are liberalised, however, capital owners have the option to invest capital abroad and, as we shall

\footnotetext{
${ }^{10}$ Contrary to partial equilibrium settings, where firms take as given the interest rate and union bargaining power leads to underinvestment (see, e.g., Grout 1984), in our general equilibrium setting the effect of union bargaining power is to reduce interest rates (since demand of capital eventually decreases, although supply remains constant).
} 
see below, the impact of increased union power on workers' welfare may become negative.

\section{Capital mobility}

We assume that capital owners can invest their endowments in both countries, even though those capital movements are not accompanied by physical movements of capitalists. Their investment decision depends on the return on capital in countries $A$ and $B$.

4.1. Equilibrium. Under free capital mobility, in addition to (1) and (2), a no-arbitrage condition in the world capital market $\left(r^{A}=r^{B}\right)$ needs to be satisfied together with the world capital market clearing condition. Accordingly, the equilibrium levels of $K^{A}$ and $K^{B}$ are derived by solving the following equations

$$
\begin{aligned}
\left(1-\gamma^{A}\right) F_{K}\left(K^{A}, \bar{N}\right) & =\left(1-\gamma^{B}\right) F_{K}\left(K^{B}, \bar{N}\right) \\
K^{A}+K^{B} & =2 \bar{K} .
\end{aligned}
$$

From the no arbitrage condition in the capital market (6), and by use of (7), it can be checked that if $\gamma^{A}=\gamma^{B}$ then the solution $K^{A}=K^{B}=\bar{K}$ would be obtained, which is identical to the solution under autarky. Indeed, if the two countries were characterised by the same union bargaining power, no capital movements would be observed, and the equilibrium solution would precisely be the efficient one. Therefore, the no-arbitrage condition above implies that capital movements are induced by differences in union power.

Hereafter, we denote unions bargaining power in country $A$ by $\gamma^{A}=\gamma$ and, to simplify matters, we assume that in country $B$ there is perfect competition in the labour market, that is $\gamma^{B}=0$. Accordingly, we impose the following,

Assumption 2. $\gamma^{A}=\gamma$ and $\gamma^{B}=0$. 
In the lemma below we state conditions under which an equilibrium exists and is unique.

Lemma 1. Assume that $\lim _{K^{A} \rightarrow 0} F_{K}\left(2 \bar{K}-K^{A}, \bar{N}\right)-(1-\gamma) F_{K}\left(K^{A}, \bar{N}\right)<0$ and $\lim _{K^{A \rightarrow 2 \bar{K}}} F_{K}\left(2 \bar{K}-K^{A}, \bar{N}\right)-(1-\gamma) F_{K}\left(K^{A}, \bar{N}\right)>0$. Then, under capital mobility there is a unique solution $\left(K^{A}, K^{B}\right)$ satisfying $K^{B}>\bar{K}>K^{A}$.

Proof. By use of (7), and given Assumption 2, (6) can be written as $Z\left(K^{A}\right) \equiv$ $F_{K}\left(2 \bar{K}-K^{A}, \bar{N}\right)-(1-\gamma) F_{K}\left(K^{A}, \bar{N}\right)$, and a solution for $K^{A}$ satisfies $Z\left(K^{A}\right)=0$. Given Assumption 1, $Z$ is a continuous increasing function of $K^{A}$, taking values in $\left(\lim _{K^{A} \rightarrow 0} Z\left(K^{A}\right) ; \lim _{K^{A} \rightarrow 2 \bar{K}} Z\left(K^{A}\right)\right)$. Hence, $Z\left(K^{A}\right)$ takes the value zero for some $K^{A} \in(0,2 \bar{K})$, provided that $\lim _{K^{A} \rightarrow 0} Z\left(K^{A}\right)<0$ and $\lim _{K^{A} \rightarrow 2 \bar{K}} Z\left(K^{A}\right)>0$. Moreover, $Z(\bar{K})=F_{K}(\bar{K}, \bar{N})-(1-\gamma) F_{K}(\bar{K}, \bar{N})=\gamma F_{K}(\bar{K}, \bar{N})>0 ;$ therefore, since $Z\left(K^{A}\right)$ is an increasing function of $K^{A}$, it can only become zero for $K^{A}<\bar{K}$.

From Lemma 1, equilibrium capital services are higher in country $B\left(K^{B}>\right.$ $\left.\bar{K}>K^{A}\right)$, that is capital flows from the more to the less unionised country. These capital outflows from country $A$ imply in turn that workers' income in the unionised country is lower under capital mobility than under autarky. In view of (2), and using of the Euler relations, we can derive the effect of capital mobility on workers' income in country $A$, that is

$$
\frac{d w^{* A}}{d K^{A}}=\frac{K^{A}}{\bar{N}}\left(\gamma \frac{F_{K}^{A}}{K^{A}}-(1-\gamma) F_{K K}^{A}\right)>0,
$$

where $F_{K}^{j} \equiv F_{K}\left(K^{j}, \bar{N}\right)$ and $F_{K K}^{j} \equiv F_{K K}\left(K^{j}, \bar{N}\right), j=A, B$. By Assumption 1 , the expression $\frac{d w^{* A}}{d K^{A}}$ takes positive values. Since the utilization of capital services in country $A$ is smaller under capital mobility than under autarky, (8) implies that workers' income in the unionised country decreases when international capital movements are liberalised. Obviously, capitalists' income in country $A$ increases, since the return to capital is a decreasing function of $K^{A}$. 
Let us now study the effects of capital mobility on total income of country $A$. Gross national product in the unionised country amounts to $X^{A}=F\left(K^{A}, \bar{N}\right)+$ $F_{K}^{B}\left(K^{B}-\bar{K}\right) \cdot{ }^{11}$ Differentiating the latter expression with respect to $K^{A}$ and by use of (7) we obtain,

$$
\frac{d X^{A}}{d K^{A}}=\left[F_{K}^{A}-F_{K}^{B}-F_{K K}^{B}\left(K^{B}-\bar{K}\right)\right]>0
$$

This expression takes a value zero at the autarkic solution, since $K^{A}=K^{B}=\bar{K}$; and becomes positive as soon as capital mobility is allowed. Indeed $\frac{d X^{A}}{d K^{A}}>0$ since: $F_{K K}^{B}<0$ by Assumption 1 and, at equilibrium, $\left(K^{B}-\bar{K}\right)>0$ and $F_{K}^{A}>F_{K}^{B}$ under Assumption 2. Accordingly, moving from autarky to free capital mobility implies that the unionised country experiences a loss in national income.

Deriving the effect of capital liberalisation in country $B$ is straightforward. Since gross national product under capital mobility is given by $X^{B}=F\left(K^{B}, \bar{N}\right)$ $F_{K}^{B}\left(K^{B}-\bar{K}\right)$, taking into account $(7)$ we have,

$$
\frac{d X^{B}}{d K^{A}}=F_{K K}^{B}\left(K^{B}-\bar{K}\right)<0 .
$$

Accordingly, $X^{B}$ increases as $K^{A}$ decreases and thus income in the competitive country is higher under capital mobility than under autarky. Obviously, wages in country $B$ increase (the capital rental rate decreases), since Euler relations together with concavity of $F$ require that the marginal productivity of labour (of capital) is an increasing (decreasing) function of $K$.

World output reads as $Y^{T}=F\left(K^{A}, \bar{N}\right)+F\left(K^{B}, \bar{N}\right)$, therefore,

$$
\frac{d Y^{T}}{d K^{A}}=F_{K}^{A}-F_{K}^{B}>0
$$

\footnotetext{
${ }^{11}$ Since capital movements are not accompanied by physical movements of capital owners, we need to distinguish between national and domestic product.
} 
With international capital flows $F_{K}^{A}>F_{K}^{B}$, hence as $K^{A}$ decreases world output decreases as a result of the inefficient allocation of capital across countries. Accordingly, we can establish the following.

Proposition 2 . Under capital mobility, income in the unionised country and in the world is lower than under autarky.

Due to the different degree of distortion in labour markets the rental rate of capital is higher in the less unionised country, thus inducing inefficient capital movements; output in this country increases but at the expense of an even higher decrease of output in the more unionised country, thus leading to lower world output.

Note that capital share in domestic output in country $A$ is increasing in $K^{A}$. Hence, recalling that under autarky $s_{K}^{A}<s_{K}^{B}$, capital mobility further reduces the unionised country's share of capital in output. ${ }^{12}$ The workers' share of world output at the free capital mobility equilibrium is given by $\frac{w^{* A} \bar{N}+w^{B} \bar{N}}{Y^{T}} \equiv \frac{F^{A}}{Y^{T}} s_{L}^{A}+\frac{F^{B}}{Y^{T}} s_{L}^{B}$. By use of (3), (4) and (6), and after straightforward calculations, it follows that, $\operatorname{sign}\left\{\frac{d\left(\frac{w^{* A} \bar{N}+w^{B} \bar{N}}{Y^{T}}\right)}{d K^{A}}\right\}=\operatorname{sign}\left\{\left(s_{K}^{B}-s_{K}^{A}\right)\left(\frac{\gamma F^{B}}{F^{A}+F^{B}}+(1-\gamma) \frac{1}{\sigma}\right)+\gamma(1-\gamma)\left(1-\frac{1}{\sigma}\right) \frac{F_{K}^{A} K^{A}}{F^{A}}\right\}$.

Since the share of capital in output is lower in the unionised than in the non unionised country, then, liberalisation of capital movements brings about an increase in the share of world output of capital owners at the expense of workers' share of world output. ${ }^{13}$

4.2. Changes in relative bargaining power. We now study how, in a world characterised by internationally mobile capital, a change of the bargaining

\footnotetext{
${ }^{12}$ Formally, differentiating $s_{K}^{A} \equiv \frac{(1-\gamma) F_{K}^{A} K^{A}}{F^{A}}$ with respect to $K^{A}$ and using Assumption 1, gives $\frac{d s_{K}^{A}}{d K_{13}^{A}}=\frac{s_{K}^{A}}{K^{A}}\left(1-\frac{1}{\sigma}\right) \frac{F_{L}^{A} \bar{N}}{F^{A}}>0$. assets). Had we not allowed for private pension assets, we would have observed even larger losses in workers' share of world output.
} 
strength of workers, relative to firms in country $A$, affects the equilibrium. Totally differentiating (6) with respect to $\gamma$, and accounting for (7), gives us the impact of a change in union power on equilibrium capital levels, that is,

$$
\frac{d K^{A}}{d \gamma}=\frac{F_{K}^{A}}{F_{K K}^{B}+(1-\gamma) F_{K K}^{A}}<0
$$

Clearly, $\frac{d K^{B}}{d \gamma}=-\frac{d K^{A}}{d \gamma}>0$. Accordingly, an increase in union power in country $A$ widens the difference in returns of capital across countries, favouring capital movement into country $B$ even further. Since $X^{A}, X^{B}$ and $Y^{T}$ do not directly depend on $\gamma$, the effect of a change in $\gamma$ on national income in both countries, and in the world, can be obtained by use of (9)-(11) as follows

$$
\begin{aligned}
\frac{d X^{A}}{d \gamma} & =\frac{d X^{A}}{d K^{A}} \frac{d K^{A}}{d \gamma}<0 \\
\frac{d X^{B}}{d \gamma} & =\frac{d X^{B}}{d K^{A}} \frac{d K^{A}}{d \gamma}>0 \\
\frac{d Y^{T}}{d \gamma} & =\frac{d Y^{T}}{d K^{A}} \frac{d K^{A}}{d \gamma}<0 .
\end{aligned}
$$

Under autarky, capital and labour utilization in each country is fixed at equilibrium and, therefore, output is constant and unaffected by changes in union power. Equations (14)-(16) show however that, under capital mobility, a higher union power implies a net loss in national income in the unionised country and in the world (and a net gain in the competitive country). The following proposition summarizes this result.

Proposition 3 . Under capital mobility, income in the unionised country and in the world is negatively correlated with union bargaining power.

Proposition 3 implies that the unionised country and the world are worse off when worker bargaining strength increases, due to the higher distortion in the 
unionised country labour market and the induced inefficient capital movements. The competitive country, however, is better off for higher values of $\gamma$.

We now ask if, given internationally mobile capital, an increase in union power can, after all, benefit workers in the unionised country. To study the sign of the correlation between union power and workers' income in the unionised country under capital mobility, we totally differentiate (2) with respect to $\gamma$ and obtain

$$
\left.\frac{d w^{* A}}{d \gamma}\right|_{M o b}=F_{K}^{A} \frac{K^{A}}{\bar{N}}+\frac{d w^{* A}}{d K^{A}} \frac{d K^{A}}{d \gamma}
$$

where $\frac{d w^{* A}}{d K^{A}}$ is given by (8). The expression above reflects the fact that an increase in $\gamma$ affects workers' income through two channels (see 2). A direct channel, which raises the workers' income share for a given level of output; and an indirect channel linked to the capital outflow triggered by the increase in union power. The effect working through the first channel is positive; it is represented by the term $F_{K}^{A} \frac{K^{A}}{N}$ in (17) and is analogous to what happens under autarky (see 5). The second channel bears two effects, the sum of which is captured by the second term on the rhs of (17). In view of (2) these two effects are: (i) A decrease in the marginal productivity of labour (i.e., $\left.F_{L}^{A}\right)$; (ii) A change in the marginal contribution of capital to output (i.e., $F_{K}^{A} K^{A}$ ). The latter cannot be signed a priori, since it depends on the elasticity of substitution between capital and labour. However, using (8) and (13), it can be checked that the sum of the two effects is unambiguously negative, implying that $\left.\frac{d w^{* A}}{d \gamma}\right|_{M o b}<\left.\frac{d w^{* A}}{d \gamma}\right|_{A u t}=F_{K}^{A} \frac{K^{A}}{N}$. Accordingly, we have the following result.

Proposition 4 . Under capital mobility, an increase (decrease) in union bargaining power increases (decreases) workers' income by less than under autarky.

Although changes in union power do not affect national product nor world output at the autarkic equilibrium, they do affect its distribution between capital owners and workers. As seen earlier, union power and workers' income in the unionised 
country are positively correlated under autarky. However, whether under capital mobility an increase in union power is able to increase workers' income at all depends on the overall sign of (17). By use of (8) and (13) it can be easily checked that $\operatorname{sign}\left\{\left.\frac{d w^{* A}}{d \gamma}\right|_{M o b}\right\}=-\operatorname{sign}\left\{\gamma \frac{F_{K}^{A}}{K^{A}}+F_{K K}^{B}\right\}$, which yet again depends on the elasticity of substitution between capital and labour, as well as on the levels of $K^{A}$ and $K^{B}$. Given Assumptions 1 and 2, the following result applies.

Proposition 5 . Under capital mobility, there is a threshold value $\gamma^{*}$ above (below) which workers' income in the unionised country decreases (increases) with $\gamma$.

Proof. Using (6)-(7), we obtain that $\operatorname{sign}\left\{\left.\frac{d w^{* A}}{d \gamma}\right|_{M o b}\right\}=\operatorname{sign}\left\{(1-\gamma) \frac{s_{L}^{B}}{\sigma} \frac{K_{A}}{K_{B}}-\gamma\right\}$. The latter expression is a continuous decreasing function of $\gamma \in[0,1)$, taking all values in $\left[\frac{s_{L}^{B}}{\sigma} \frac{K_{A}}{K_{B}},-1\right)$. Hence there is a critical value $\gamma^{*}$ at which $\left.\frac{d w^{* A}}{d \gamma}\right|_{M o b}=0$ and thus $\left.\frac{d w^{* A}}{d \gamma}\right|_{M o b}>0$ for $\gamma<\gamma^{*}$ and $\left.\frac{d w^{* A}}{d \gamma}\right|_{M o b}<0$ for $\gamma>\gamma^{*}$.

Proposition 5 means that unions that are willing to maximize workers income, under internationally mobile capital, face a critical level of bargaining power, $\gamma^{*}$; pushing their bargaining power beyond that level will only hurt workers.

\section{Conclusions}

We have shown that, if one country is unionised whereas the other is not, unions will always prefer autarky but the competitive country and its workers will be better off under free movements of capital. Capital owners, on the other hand, benefit from capital movement liberalisation when this is induced by the presence of unions in their domestic market, whereas those residing in the competitive country would suffer a decrease in their per capita income. The aggregate gain though is negative, since capital flows are induced by a distortion in returns.

With capital internationally mobile, however, the world would gain if the non unionised country were to converge to the same degree of unionization of the other 
country. In this case no factor movements would occur at equilibrium, and workers of the unionised country would also be better off. Accordingly, for workers in unionised countries it makes sense to push towards achieving, prior to integration, similar levels of bargaining strength around the world. In contrast, under asymmetric unionization and integrated goods and capital markets, if workers' bargaining strength in the unionised country is relatively high, a reduction in union power actually benefits union members, as it limits the size of capital flows out of the unionised country and its negative effects on labour productivity and on the marginal contribution of capital to output.

\section{References}

[1] Bordo, M.,Taylor A. M., Williamson J. G. (eds), 2003, Globalization in Historical Perspective, Chicago: University Press

[2] Grout, P.A., 1984, "Investment and wages in the absence of binding contracts", Econometrica 52, 449-460

[3] Katz, H. C., 1993, "The decentralization of collective bargaining: a literature review and comparative analysis", Industrial and Labor Relations Review 47, 3-22

[4] ILO, 1999, Progress Report on the Country Studies on the Social Impact of Globalisation, Geneva

[5] Scheve, K., and Matthew Slaughter, 2001, Globalization and the Perceptions of American Workers, Washington DC: Institute for International Economics 